\title{
Potential Regulatory Effects of Corticotropin-Releasing Factor on Tight Junction-Related Intestinal Epithelial Permeability are Partially Mediated by CK8 Upregulation
}

\author{
Hu Yue Lu Bin Chen Chaoying Zhang Meng Li Meng Wang Xi \\ Department of Gastroenterology, First Affiliated Hospital of Zhejiang Chinese Medical University, \\ Hangzhou, China
}

\section{Key Words}

Intestinal epithelial permeability - Cytokeratin 8 - Corticotropin-releasing factor - Tight junction protein $\cdot$ RhoA

\begin{abstract}
Background/Aims: Intestinal permeability and stress have been implicated in the pathophysiology of irritable bowel syndrome (IBS). Cytokeratin 8 (CK8), for the first time, has been shown to mediate corticotropin-releasing factor (CRF)-induced changes in intestinal permeability in animal models of IBS. In this study, we investigated the regulatory effects of CRF on the permeability of human intestinal epithelial cells through the CK8-mediated tight junction. Methods: The expression levels of corticotropin-releasing factor receptor 1 (CRFR1) and corticotropin-releasing factor receptor 2 (CRFR2) on the HT29 cell surface were determined by immunofluorescence, RT-PCR, and Western blotting. After treatment with $100 \mathrm{nM}$ CRF for $72 \mathrm{~h}$, the translocation of FITC-labelled dextran was measured in a transwell chamber; the structural changes of tight junctions were observed under transmission electron microscopy; the expression levels of CK8, F-actin and tight junction proteins ZO-1, claudin-1, and occludin were detected by immunoblotting and immunofluorescence. The activity of RhoA was detected by immunoprecipitation. Furthermore, the effects of CRF on intestinal epithelial permeability were examined in CK8-silenced HT29 cells, which were constructed by shRNA interference. Results: CRF treatment increased FITC-labelled dextran permeability, caused the opening of tight junctions, induced increased fluorescence intensity of CK8 and decreased the intensities of ZO-1, claudin-1, and occludin, together with structural disruption. The expression levels of F-actin, occludin, claudin-1, and ZO-1 were downregulated. RhoA activity peaked at $30 \mathrm{~min}$ after CRF treatment. CRF-induced increased permeability, and downregulation of claudin-1 and occludin were not blocked by CK8 silencing. Nevertheless, CK8 silencing blocked the effects of CRF regarding the decrease in the expression levels of F-action and ZO-1 and
\end{abstract}




\section{Cellular Physiology Cell Physiol Biochem 2017;44:1161-1173 \\ \begin{tabular}{l|l|l} 
DOI: 10.1159/000485420 & $\begin{array}{l}\text { O 2017 The Author(s). Published by S. Karger AG, Basel } \\
\text { www.karger.com/cpb }\end{array}$
\end{tabular} \\ Yue et al.: CRF Regulates Intestinal Epithelial Permeability by CK8 Upregulation}

increase in RhoA activity. Conclusion: CRF may increase intestinal epithelial permeability by upregulating CK8 expression, activating the RhoA signalling pathway, promoting intestinal epithelial actin remodelling, and decreasing the expression of the tight junction protein ZO-1. Other CK8-independent pathways may be involved in the downregulation of claudin-1 and occludin, which might also contribute to increased intestinal epithelial permeability.

\section{Introduction}

(C) 2017 The Author(s)

Published by S. Karger AG, Basel

Irritable bowel syndrome (IBS) is one of the most common clinical gastrointestinal disorders [1]. The pathogenesis of IBS is not completely understood and has been a barrier for the development of effective treatment modalities. IBS seriously affects the quality of life of the afflicted individual. Studies have documented evidence of an impaired mucosal barrier in the small intestines and colons of patients who have IBS with diarrhoea (IBS-D) [2]. In addition, Vivinus-Nébot et al. reported a significant increase in the permeability of intestinal epithelial cells during episodes of IBS-associated diarrhoea [3]. These findings suggest that the intestinal epithelial barrier plays a crucial role in the pathogenesis of IBS-D. Maintaining the structural and functional integrity of the intestinal epithelial barrier is believed to be a key approach to the prevention and treatment of IBS.

Tight junctions (TJs) are the most important constituents of the intestinal epithelial barrier [4]. TJs help maintain the structural integrity of epithelial cells, control the transport of molecules and ions, and regulate the permeability of the intestinal epithelial barrier [5-6]. Moreover, TJs regulate the polarity and phenotype of intestinal epithelial cells through twoway signal transduction between the intra- and extracellular environment [7]. TJs comprise a branching network of strands, composed of various TJ proteins. The transmembrane proteins occludin and claudin-1 are embedded in the plasma membrane and are related to cytoplasmic proteins such as ZO-1, which are key molecules that form the TJs of the intestinal epithelium. ZO-1 anchors the strands to the cytoskeleton through binding with actin to help maintain the functional stability of TJs $[3,8]$. The altered structure or expression of these proteins impairs the integrity of TJs, leading to the increased permeability of the intestinal mucosa to pathogens, endotoxins, and toxic macromolecules. In both IBS patients and animal models of IBS, increased intestinal epithelial permeability has been shown to be closely related to changes in the expression and distribution of T]s [3, 9-12].

Cytokeratin 8 (CK8) is a keratin protein present in the intermediate filaments of epithelial cells and shows stress-related expression. Zupancic et al. first reported that CK8 mutations could cause dysfunction of the intestinal epithelial barrier and abnormal distribution of T] proteins Claudin-4 and ZO-1 [13]. CK8 overexpression has been shown to induce degradation and remodelling of actin and tubulin [14-17]; its negative correlation with TJ-related proteins has also been reported [18]. Moreover, in our previous study, CK8 expression was found to be significantly increased in the ileocaecal intestinal mucosa of stressed IBS rats [19]. Furthermore, we found increased expression of CK8 in colonic epithelial cells of rats with IBS, along with the remodelling of actin and dysfunctional distribution of claudin- 1 and ZO-1. These findings suggest that CK8-mediated actin remodelling and TJ injury may play an important role in the increased intestinal epithelial permeability of IBS-D.

Corticotropin-releasing factor (CRF) is one of the most important endocrine hormones of the stress response and has a proven role in the development and progression of IBS [20-23]. Some recent studies have shown that CRF may cause changes in the expression and distribution of TJ proteins [24,25], resulting in the increased permeability of intestinal epithelial cells [26]. Moreover, CRF can induce changes in keratin expression [27, 28]. Our previous studies have shown that CRF is associated with the upregulation of CK8 expression in the colonic epithelium of an IBS model. In this study, we sought to clarify whether CRFinduced (or CRF-associated) upregulation of CK8 expression is involved in mediating the increased intestinal epithelial permeability in the context of IBS. This study was designed to provide a scientific basis for the pathogenesis, diagnosis, and treatment of IBS-D.

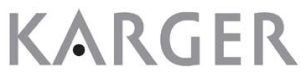




\section{Cellular Physiology Cell Physiol Biochem 2017;44:1161-1173 \begin{tabular}{l|l|l} 
and Biochemistry Published online: November 28, 2017 & $\begin{array}{l}\text { (c) } 2017 \text { The Author(s). Published by S. Karger AG, Basel } \\
\text { www.karger.com/cpb }\end{array}$
\end{tabular}

\section{Materials and Methods}

\section{Cell culture}

The human colonic cancer cell line HT29 was purchased from the Shanghai Cell Bank of Chinese Academy of Sciences and was incubated in RPMI 1640 medium (Gibco, NY, USA) containing 10\% FBS (Gibco, NY, USA) at $37^{\circ} \mathrm{C}$ in a $5 \% \mathrm{CO}_{2}$ incubator. The cells were adherent and were subcultured at 2-3 days. When grown to approximately 60-70\% monolayer confluence, HT29 cells were treated with $100 \mathrm{nM}$ CRF (Tocris, Bristol, UK) for $72 \mathrm{~h}$ and were examined $72 \mathrm{~h}$ post-treatment.

\section{CK8 shRNA lentiviral infection}

Cells in the logarithmic growth phase were digested with trypsin and were suspended in complete medium at a density of 3-5 × 104 cells/mL; next, a 2-mL cell suspension was inoculated onto a 6-well plate. When the cell density reached $20 \%$ per well, the medium was replaced with infection medium (Eni.S + 5 $\mu \mathrm{g} / \mathrm{mL}$ polybrene) containing CK8 interference lentivirus (LV-KRT8-RNAi, 37991-1) (Genechem, Shanghai, China) for the sh-CK8 group or negative control virus CON053 for the sh-NC group at an MOI of 20. The culture medium was replaced with normal medium at $16 \mathrm{~h}$ after infection. At $72 \mathrm{~h}$ after infection, the cells were treated with $100 \mathrm{nM} \mathrm{CRF}$ and were subjected to different examinations at the designated time points.

\section{Immunofluorescence assay}

HT29 cells were adjusted to a concentration of $5 \times 10^{5} /$ well, inoculated into 24 -well plates with rounded plates, and incubated at $37^{\circ} \mathrm{C}$ in a $5 \% \mathrm{CO}_{2}$ incubator (Thermo, Massachusetts, USA). The rounded plates were washed three times with phosphate-buffered saline (PBS) (Gibco, NY, USA), fixed with 4\% paraformaldehyde for $10 \mathrm{~min}$, washed again with PBS for $5 \mathrm{~min}$ and repeated three times, and incubated with blocking solution for $30 \mathrm{~min}$; this step was followed by a PBS wash for $5 \mathrm{~min}$ that was repeated three times. Antibodies against CRF1 (1: 50, Anbobio, Shanghai, China), CRFR2 (1: 50, Anbobio, Shanghai, China), CK8 (1: 25000, Abcam, Cambridge, UK), F-actin (1: 500, Abcam, Cambridge, USA), Claudin-1 (1: 1000, CST, Massachusetts, USA), ZO (8 $\mu \mathrm{L} / \mathrm{mL}$, life, Massachusetts, USA), and occludin (1: 50, 000, CST, Massachusetts, USA) were used. The cells were incubated overnight with the respective antibodies at $4^{\circ} \mathrm{C}$ in a humid chamber, washed with PBS for 10 min thrice, incubated with Cy3 secondary antibodies (Sigma, St. Louis, USA) at 1: 400 in the dark for $1 \mathrm{~h}$ at room temperature, washed thrice with PBS for $10 \mathrm{~min}$ each, stained with DAPI for $15 \mathrm{~min}$, washed for $5 \mathrm{~min}$ with PBS three times, and blocked with an anti-quencher. Images were captured using BD Pathway 435 High Content Bioimagers and were processed using COMOS software (Siemens, USA).

\section{Reverse transcription-polymerase chain reaction (RT-PCR)}

Total RNA was extracted from normal HT29 cells using an RNA extraction kit (Omega, USA). cDNA was synthesized using a reverse transcription kit, and target genes were amplified by polymerase chain reaction (PCR) using a PCR machine (Bio-Rad, California, USA). The primer sequences are as follows:

Human CRFR1 Forward: AAGTCAGGTGTCATCATC, Human CRFR1 Reverse: TTTCCCAATAATCTCCATG;

Human CRFR2 Forward: TCCACAGCATCAAGCAGACG, Human CRFR2 Reverse: CAGCACAGAGAACCCAGAGGA.

The total PCR reaction volume was $10 \mu \mathrm{L}$, containing $5 \mu \mathrm{L}$ of $2 \times$ SYBR Premix Ex Taq (Tli RNaseH Plus) (Takara, Kyoto, Japan) working solution, $0.2 \mu \mathrm{L}$ each of the upstream and downstream primers, $0.2 \mu \mathrm{L}$ of $50 \times$ Rox reference dye, and $3.4 \mu \mathrm{L}$ of PCR-grade water. PCR was conducted at $95.0^{\circ} \mathrm{C}$ for $30 \mathrm{~s}$ for predenaturation, followed by 40 cycles of amplification: $95.0^{\circ} \mathrm{C}$ for $5 \mathrm{~s}$ for annealing and $60.0^{\circ} \mathrm{C}$ for $34 \mathrm{~s}$ for extension. Next, $10 \mu \mathrm{L}$ of amplified product was separated by $2 \%$ agarose gel electrophoresis. Images were collected by a gel imaging system, and data were analysed using Quantity One software (Bio-Rad, California, USA). The PCR results of the human neuroblastoma cell line IMR-32 were used as a positive control.

\section{Western Blot analysis}

The HT29 cells were harvested, washed with PBS, and lysed in RIPA lysis buffer. The protein was collected, and the concentration was determined by the BCA protein assay method. Samples were loaded through a $10 \%$ SDS-PAGE and then were transferred to a polyvinylidene fluoride (PVDF) membrane. The membrane was blocked with 5\% non-fat milk at room temperature for $1 \mathrm{~h}$ and then was incubated 


\section{Cellular Physiology Cell Physiol Biochem 2017;44:1161-1173

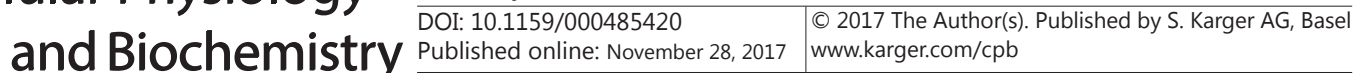 \\ Yue et al.: CRF Regulates Intestinal Epithelial Permeability by CK8 Upregulation}

overnight with antibodies against CRF1 (1: 1000, Anbobio, Shanghai, China), CRFR2 (1: 1000, Anbobio, Shanghai, China), CK8 (1: 25000, Abcam, Cambridge, UK), F-actin (1: 500, Abcam, Massachusetts, USA), claudin-1 (1: 1000, CST, Massachusetts, USA), ZO-1 (8 $\mu \mathrm{L} / \mathrm{mL}$, Life Technologies, Massachusetts, USA), and occludin (1: 50000, CST, Massachusetts, USA) at $4^{\circ} \mathrm{C}$, followed by incubation with their respective secondary antibodies at room temperature for $2 \mathrm{~h}$, and washing with $1 \times$ TBST 3 times. The membrane was subjected to examination using the ECL chemiluminescence kit. Images were collected using a gel imaging system, and the data were analysed by Quantity One. The CRF receptor protein in mouse hypothalamus was used as the positive control.

\section{Cellular permeability analysis}

HT29 cells in the logarithmic growth phase were seeded onto transwell plates at a density of $1 \times 10^{5}$. After the cells grew to a monolayer, $100 \mu \mathrm{M}$ CRF was contained in the culture medium (the upper layer was added to $200 \mu \mathrm{L}$, the lower layer was added to $600 \mu \mathrm{L}$ ). After $72 \mathrm{~h}$, the transwell plates were washed twice with PBS, and $100 \mu \mathrm{L}$ of $1 \mathrm{mg} / \mathrm{mL}$ fluorescein isothiocyanate (FITC)-labelled dextran (Sigma, St. Louis, USA) was added to the upper chamber; $500 \mu \mathrm{L}$ of PBS was added to the upper and lower chambers prior to incubation in the dark at $37^{\circ} \mathrm{C}$. Next, $100 \mu \mathrm{L}$ of PBS was collected from the bottom of the transwell plate at $0.5,1$, and $2 \mathrm{~h}$, followed by transfer to a 96-well plate. The plate was measured using a fluorescence spectrophotometer at an excitation wavelength of $488 \mathrm{~nm}$ and an emission wavelength of $525 \mathrm{~nm}$. The concentration of FITC-labelled dextran was calculated based on the standard curve.

\section{Electron microscopy analysis}

Cells were seeded at $1 \times 10^{5}$ per well in a 6-well plate; $72 \mathrm{~h}$ after treatment with CRF, the cells were scraped, fixed in $2.5 \%$ glutaraldehyde ( $>48 \mathrm{~h}$ ), rinsed with PBS three times for 15 min each, immobilized with $1 \%$ osmium tetroxide for $\mathrm{l} h$, and again rinsed with PBS. The cells were dehydrated in 50\%, 70\%, and $90 \%$ ethanol for $15 \mathrm{~min}$ each, then in 100\% ethanol for $20 \mathrm{~min}$, and, finally, in $100 \%$ acetone twice for 20 min per session. The cells were penetrated with acetone and embedding agent at a 1:1 volume, shaken for $2 \mathrm{~h}$ by an oscillator (Qilinbeier, Jiangsu, China), and again shaken for $2 \mathrm{~h}$ in the pure embedding agent before polymerization in the incubator at $37^{\circ} \mathrm{C}$ for $24 \mathrm{~h}, 45^{\circ} \mathrm{C}$ for $48 \mathrm{~h}$, and $60^{\circ} \mathrm{C}$ for $48 \mathrm{~h}$. Next, $120-\mathrm{nm}$ ultra-thin slices were sectioned and stained with $4 \%$ uranyl acetate for 20 min and with double electron staining with lead citrate for $5 \mathrm{~min}$. These ultra-thin sections were then placed on a single-hole copper mesh and were subjected to observation and photography under electron microscopy (TECNA110 transmission electron microscope, high voltage 80KV) (Philips, Netherlands).

\section{RhoA activity assay}

HT29 cells were cultured to $90 \%$ confluence, treated with $100 \mathrm{nM} \mathrm{CRF}$, and harvested at $5 \mathrm{~min}, 10 \mathrm{~min}$, $30 \mathrm{~min}, 1 \mathrm{~h}$, and $2 \mathrm{~h}$. The cells were then washed once with cold PBS, lysed with RIPA lysate, and centrifuged for $15 \mathrm{~min}$ at $12,000 \mathrm{~g}$. The supernatant was transferred to Eppendorf tubes for storage at $-20^{\circ} \mathrm{C} ; 100-\mu \mathrm{L}$ samples were taken from each tube for immunoprecipitation (IP) assay, mixed with the same volume of $2 \times \mathrm{SDS}$, and heated at $95^{\circ} \mathrm{C}$ for $10 \mathrm{~min}$ in a water bath; $1.4 \mathrm{mg}$ of protein from each tube was aspirated into a new tube as the Co-Immunoprecipitation (Co-IP) group. Approximately $2 \mu \mathrm{g}$ of antibody and $20 \mu \mathrm{L}$ of beads were added to each IP system, and lysis buffer was used to bring the volume to $1400 \mu \mathrm{L}$. The reaction mixture was mixed by inversion at $4^{\circ} \mathrm{C}$ for $1 \mathrm{~h}$, centrifuged for $1 \mathrm{~min}$, followed by the addition of $1.4 \mathrm{~mL}$ of cold lysis buffer; the mixture was mixed by inversion for $10 \mathrm{~min}$ three times and was centrifuged for $5 \mathrm{~min}$ to remove the supernatant. Samples were boiled in $25 \mu \mathrm{L}$ of $1 \times$ SDS for $10 \mathrm{~min}$, subjected to $12 \%$ SDSPAGE, and then transferred to a PVDF membrane. The membrane was blocked by $5 \%$ non-fat milk at room temperature for $1 \mathrm{~h}$ and was incubated with anti-RhoA polyclonal antibody (1:1000; NewEast Biosciences, China) overnight at $4^{\circ} \mathrm{C}$, followed by incubation with secondary antibodies at room temperature for $1 \mathrm{~h}$ and washing with $1 \times$ TBST three times. The membrane was examined using the ECL chemiluminescence kit. Images were collected by a gel imaging system, and data were analysed by Quantity One.

\section{Statistical analysis}

Data pertaining to normally distributed variables were expressed as the mean \pm standard deviation ( $\overline{\mathrm{x}} \pm \mathrm{SD}$ ) and were compared by one-way ANOVA. Statistical analysis was conducted using SPSS version 20.0 software (SPSS, USA). $P<0.05$ was considered to be statistically significant. 


\section{Cellular Physiology Cell Physiol Biochem 2017;44:1161-1173 \begin{tabular}{l|l|l} 
and Biochemistry & DOI: 10.1159/000485420 & $\begin{array}{l}\text { C } 2017 \text { The Author(s). Published by S. Karger AG, Basel } \\
\text { www.karger.com/cpb }\end{array}$
\end{tabular} \\ Yue et al.: CRF Regulates Intestinal Epithelial Permeability by CK8 Upregulation}

\section{Results}

\section{Expression of CRF receptors 1 and 2 in HT29 cells}

Images from confocal microscopy revealed CRFR1- and CRFR2-specific staining in red and DAPI staining in blue, suggesting the coexpression of CRFR1 and CRFR2 on the surface of HT29 (Fig. 1A). RT-PCR showed a single band of PCR products without nonspecific amplification products. The sizes of CRFR1 and CRFR2 in HT29 cells (138 and $101 \mathrm{bp}$, respectively) were comparable to those of the positive controls from the human neuroblastoma cell line IMR-32 (Fig. 1B). Western blotting analysis revealed positive protein expression of CRFR1 and CRFR2 in HT29 cells in contrast to that in the mouse hypothalamic positive control (Fig. 1C).

\section{Effects of CRF on the permeability and ultrastructure of TJs in HT29 cells}

The results of the transwell assay showed that compared with the control group, the permeability of HT29 cells was increased at $0.5,1$, and $2 \mathrm{~h}$ after the administration of $100 \mathrm{nM}$ CRF $(P<0.05$; Fig. 2A). Electron microscopic images showed that the TJs between HT29 cells were intact, with closed channels and dense junctions (as shown by the yellow arrow); $72 \mathrm{~h}$ after treatment with $100 \mathrm{nM}$ CRF, the TJs of HT29 cells were incomplete and open channels, and the cell gap had expanded (as shown by the red arrow; Fig. 2B).

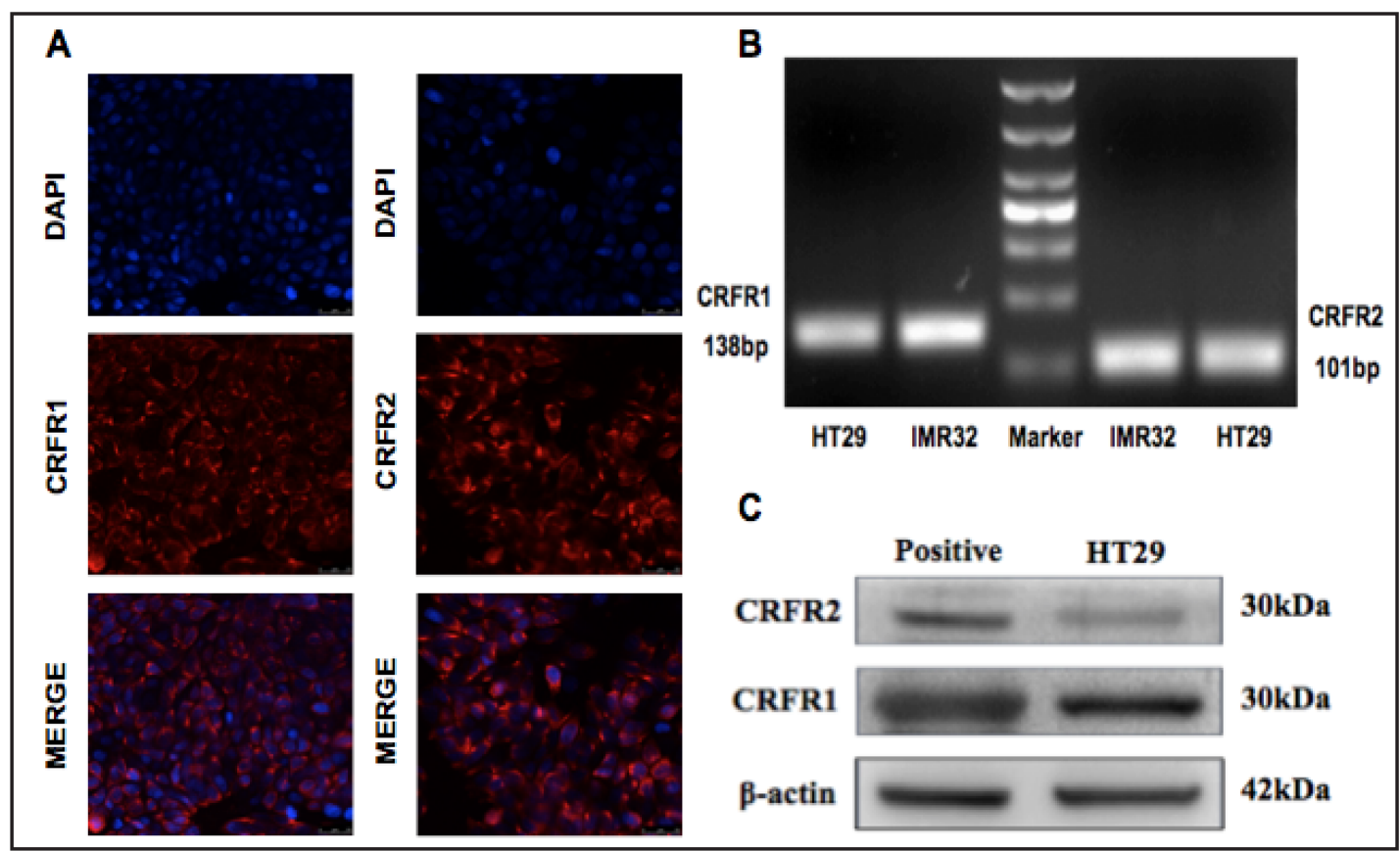

Fig. 1. The expression of CRF receptors 1 and 2 in HT29 cells was examined by immunofluorescence, RTPCR gel electrophoresis, and Western blotting. A) CRFR1 and CRFR2 expression on the HT29 cell membrane was examined after staining with Cy3-labelled antibodies (red; magnification $\times 200$ ). DAPI was used to counterstain the nucleus (blue). The overlays are also shown. B) RT-PCR gel electrophoresis to determine CRFR1 (138 bp) and CRFR2 (101 bp) mRNA levels in HT29 cells and positive control IMR32 cells. The PCR products were separated by $2 \%$ agarose gel electrophoresis. Images were captured using the Bio-Rad gel imaging system. C) Western blot analysis of CRFR1 and CRFR2 expression in HT29 cells using anti-CRFR1 and anti-CRFR2 antibodies. CRFR1 and CRFR2 expression was identified at the same size as that of the positive control (mouse hypothalamus). $\beta$-Actin was used as the loading control. Cy3: indocarbocyanin; DAPI, 4'6-diamidino-2-phenyl indoldihydrochloride. RT-PCR, reverse transcription-polymerase chain reaction; CRFR1, corticotropin-releasing factor receptor 1; CRFR2, corticotropin-releasing factor receptor 2. 


\section{Cellular Physiology Cell Physiol Biochem 2017;44:1161-1173 and Biochemistry \begin{tabular}{l|l} 
DOI: 10.1159/000485420 & $\begin{array}{l}\text { O 2017 The Author(s). Published by S. Karger AG, Basel } \\
\text { www.karger.com/cpb }\end{array}$
\end{tabular} \\ Yue et al.: CRF Regulates Intestinal Epithelial Permeability by CK8 Upregulation}

Effects of CRF on the expression and distribution of CK8, F-actin, and TJ proteins in HT29 cells

The results of Western blotting showed that CRF treatment induced significant upregulation of CK8 $(P<0.05)$ and significant downregulation of F-actin, ZO-1, claudin-1, and occludin expression in HT29 cells compared with that in the control group $(P<0.05$; Fig. 3A). Confocal microscopy showed higher fluorescence intensity and deposition of CK8 on the cell membrane after CRF treatment (Fig. 3B). No significant difference in the F-actin fluorescence intensity was observed after CRF treatment compared with that of the control (Fig. 3C). ZO-1 showed markedly low fluorescence intensity and sparse deposition on the cell membrane after CRF treatment (Fig. 3D). Furthermore, CRF treatment significantly decreased the fluorescence intensity of claudin-1 and occludin on the cell surface with structural disruptions (Fig. 3E and F).

Effects of CRF on RhoA activity in HT29 cells

Compared with the control group, RhoA activity in HT29 cells treated with CRF was gradually increased from $5 \mathrm{~min}$, peaked at $30 \mathrm{~min}(P<0.05)$, and decreased to control levels at $2 \mathrm{~h}$ (Fig. 4).

Inhibition of CK8 expression in HT29 cells by CK8 shRNA interference

Western blotting showed that the relative expression of CK8 protein in the CK8-silenced group (sh-CK8) was significantly lower than that in the control $(0.273 \pm 0.145$ vs $1.266 \pm$

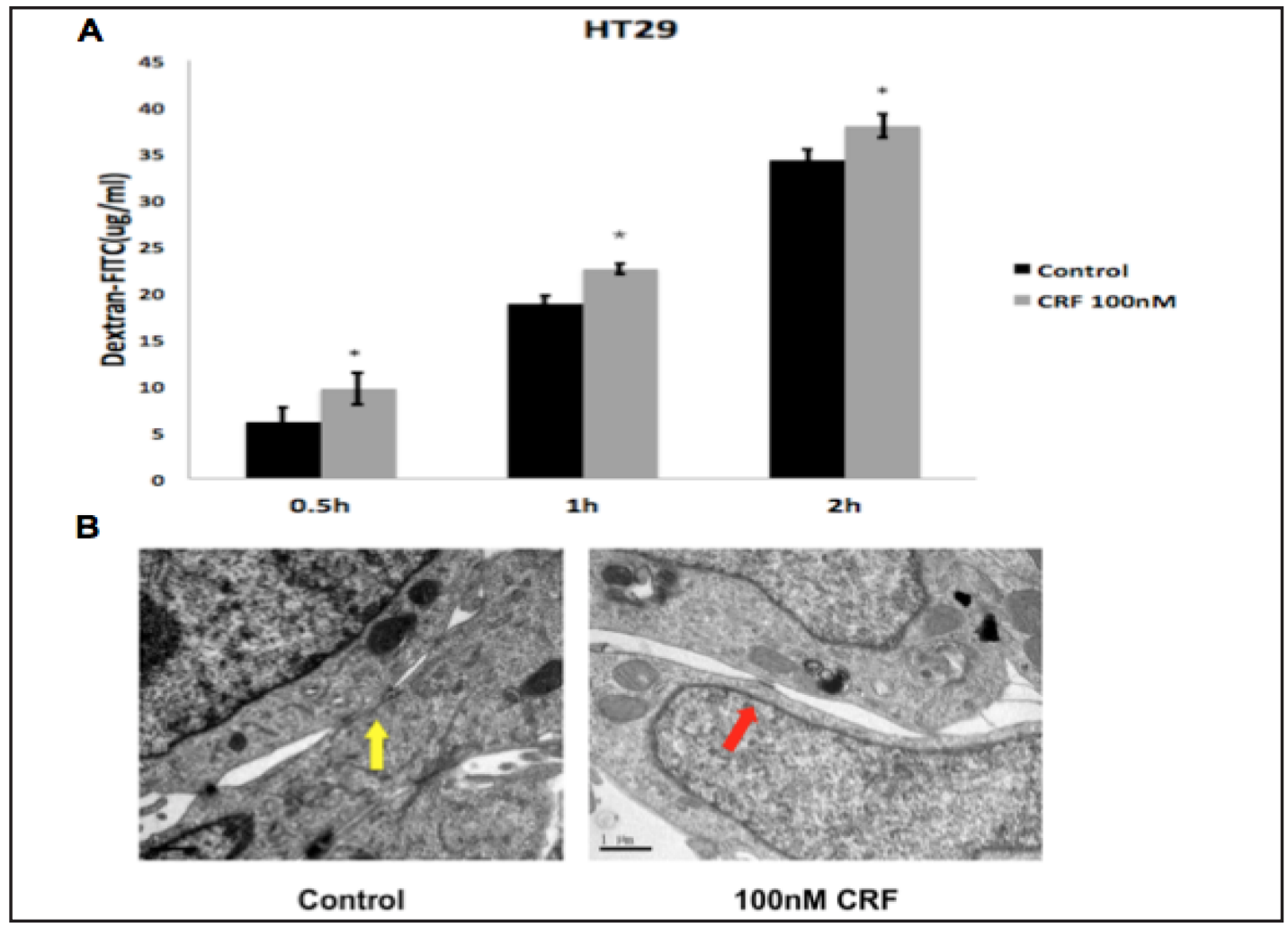

Fig. 2. Effects of CRF on the intestinal permeability and ultrastructure of tight junctions in HT29 cells. A) The intestinal permeability of HT29 cells, as indicated by FITC-dextran, was measured using a fluorescence spectrophotometer. Cells of the CRF group were treated with $100 \mathrm{nM} \mathrm{CRF}$ for $0.5,1$, and $2 \mathrm{~h}$. The values are expressed as the means $\pm S D\left(n=3\right.$ each). ${ }^{*} \mathrm{P}<0.05$ vs the respective control group. $\left.\mathrm{B}\right)$ The ultrastructure of TJs was observed under a transmission electron microscope. Cells of the CRF group were treated with $100 \mathrm{nM} \mathrm{CRF}$ for $72 \mathrm{~h}$. TJs are shown by arrows. TJs, tight junctions; FITC, fluorescein isothiocyanate; CRF, corticotropin-releasing factor.

\section{KARGER}




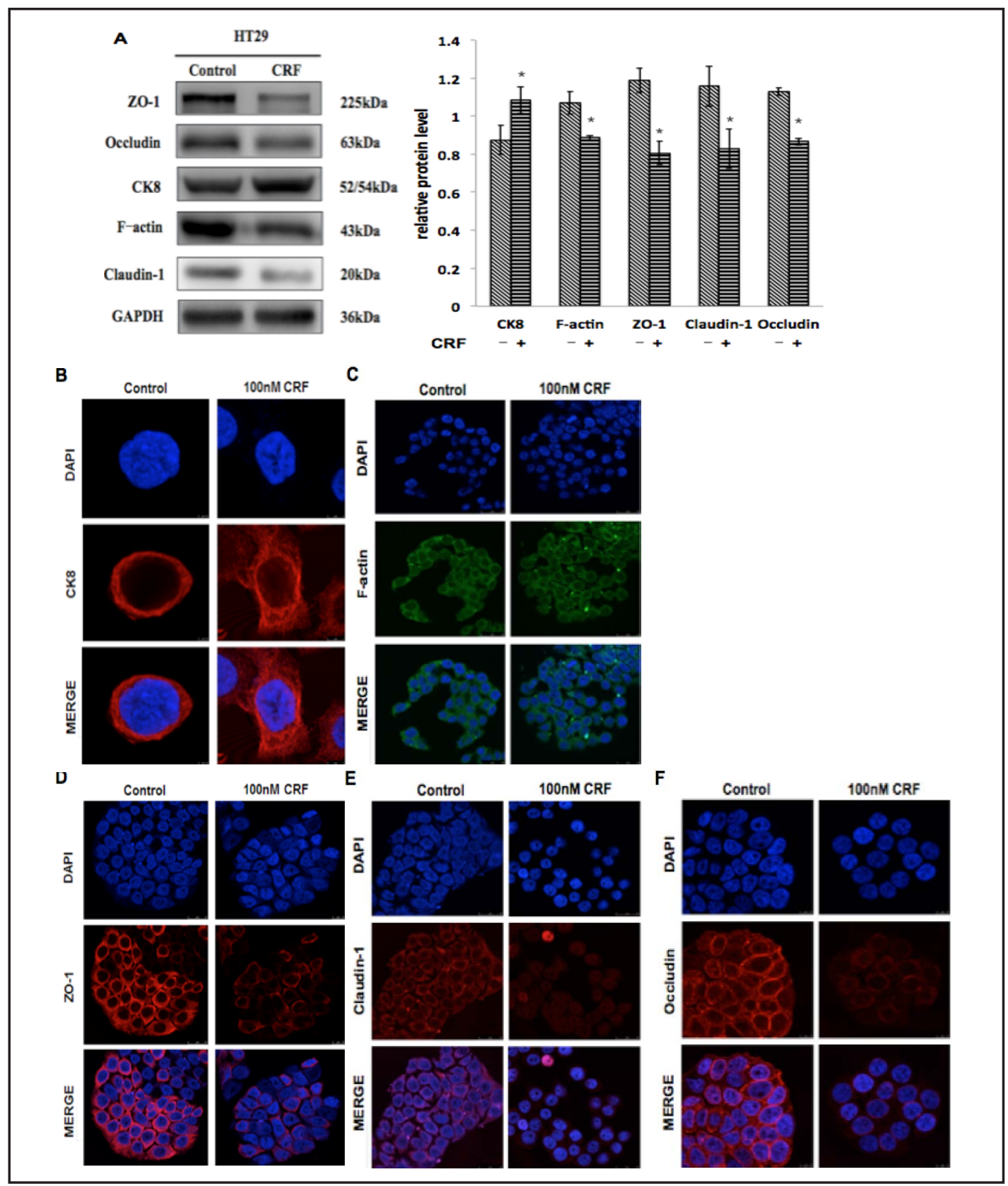

Fig. 3. Results of Western blot analysis and immunofluorescence showing the effects of CRF on the expression and distribution of CK8, F-actin, and tight junction proteins in HT29 cells. A) Western blot analysis of CK8, claudin-1, F-actin, occluding, and Z0-1 expression in HT29 cells with or without CRF treatment. GAPDH was used as the loading control. The bar chart shows the relative band intensity (CK8) GAPDH, claudin-1/GAPDH, F-actin/GAPDH, occludin/GAPDH, or ZO-1/GAPDH) as determined by scanning densitometry. The values are expressed as the means $\pm \mathrm{SD}\left(\mathrm{n}=4\right.$ each). ${ }^{*} \mathrm{P}<0.05$ vs the control group. $\left.\mathrm{B}-\mathrm{F}\right)$ Expression levels of CK8, F-actin, ZO-1, claudin-1, and occludin in HT29 cells examined under confocal microscopy. HT29 cells were stained with Cy3-labelled antibodies against CK8 (red, magnification $\times 3000$ ), ZO-1, claudin-1 (red, magnification $\times 800$ ), and occludin (red, magnification $\times 1100$ ), as well as FITC-labelled antibodies against F-actin (green, magnification $\times 630$ ). DAPI was used to counterstain the nucleus (blue). CK8, cytokeratin 8; TJs, tight junctions; CRF, corticotropin-releasing factor; GAPDH, glyceraldehyde-3phosphatedehydrogenase. Cy3: indocarbocyanin; DAPI, 4'6-Diamidino-2-phenyl indoldihydrochloride; FITC, fluorescein isothiocyanate.

\section{KARGER}


Fig. 4. Examination of RhoA activity (RhoAGTP) by Western blotting. HT29 cells were treated with $100 \mathrm{nM}$ CRF for $5 \mathrm{~min}, 10 \mathrm{~min}$, $30 \mathrm{~min}, 1 \mathrm{~h}$, and $2 \mathrm{~h}$. RhoA-GTP expression was identified compared with that of total RhoA. GAPDH was used as the loading control (not shown). The bar chart shows the relative band intensity (RhoA-

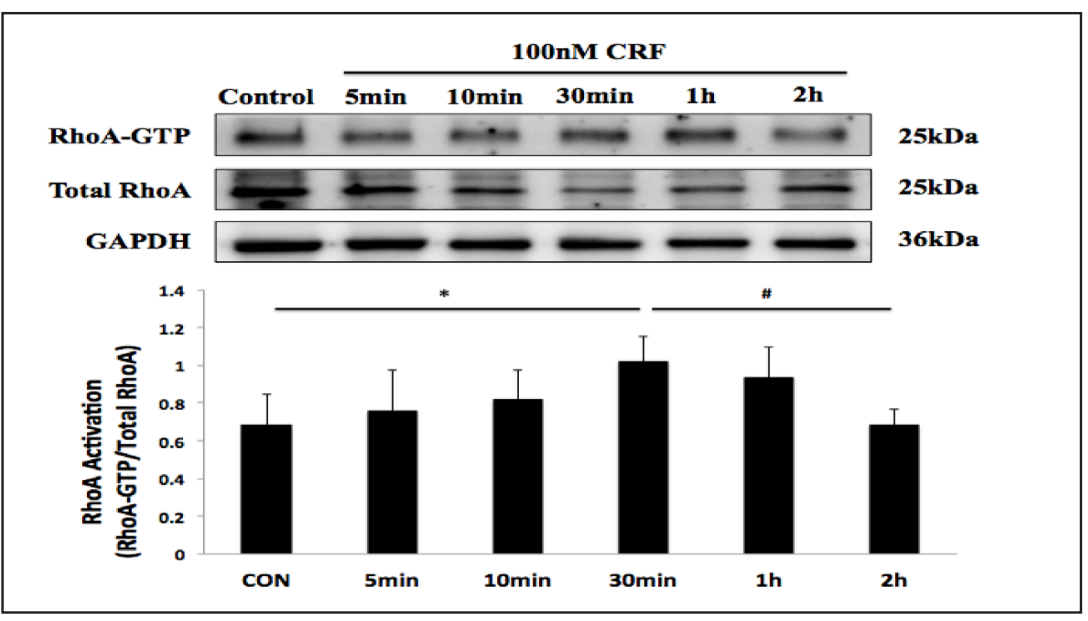
GTP/Total RhoA) as determined by scanning densitometry. The values are expressed as the means $\pm \mathrm{SD}\left(\mathrm{n}=3\right.$ each). ${ }^{*} \mathrm{P}<0.05$ vs the control; \# $\mathrm{P}<0.05$ vs the 30 -min group.RhoA, Ras homologue gene family, member A; CRF, corticotropinreleasing factor; GAPDH, glyceraldehyde-3-phosphatedehydrogenase.

Fig. 5. CK8 silencing in HT29 cells by CK8 shRNA interference. Western blot analysis revealed the significant downregulation of CK8 protein expression in the sh-CK8 group (inhibition rate of up to $79 \%$ ). GAPDH was used as the loading control. The bar chart shows the relative band intensity (CK8/GAPDH). The values are expressed as the means \pm SD ( $\mathrm{n}=3$ each). ${ }^{*} \mathrm{P}<0.01$ vs control; $\# \mathrm{P}<0.01$ vs sh-NC. CK8, cytokeratin 8; GAPDH, glyceraldehyde-3-phosphatedehydrogenase; NC, negative control.

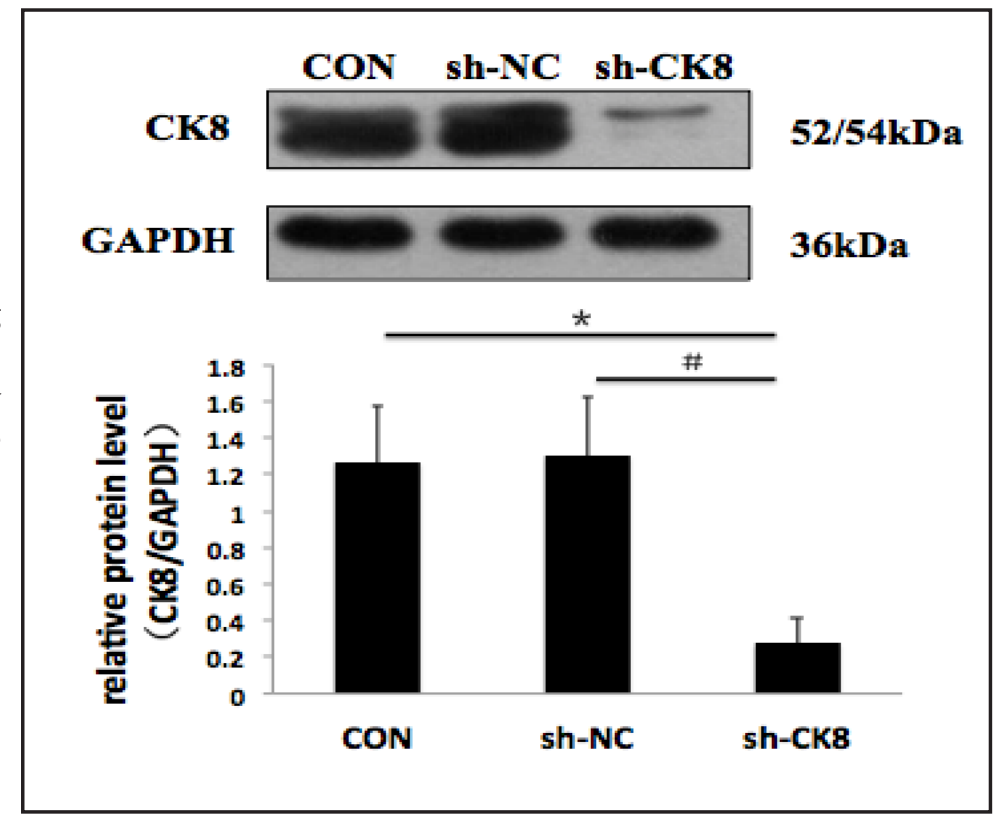

$0.313, P<0.01$ ) and negative control (sh-NC; $0.273 \pm 0.145$ vs $1.301 \pm 0.325, P<0.01$ ) groups. No difference was observed between the control and sh-NC groups with respect to CK8 protein expression. These results suggested that CK8 expression was inhibited in the sh-CK8 group (Fig. 5).

Effects of CRF on the permeability and expression of TJ-related proteins in CK8-silenced HT29 cells

The Transwell results showed no significant differences in the concentrations of FITClabelled dextran between the normal control, sh-NC, and sh-CK8 groups, suggesting that the downregulation of CK8 had no significant effect on the permeability of HT29 cells. However, treatment with CRF $(100 \mathrm{nM})$ significantly increased the concentrations of FITC-labelled dextran at $72 \mathrm{~h}$ in the 3 study groups. No difference was observed between the sh-NC and sh-CK8 groups ( $41.04 \pm 1.33 \mu \mathrm{g} / \mathrm{mL}$ vs $40.58 \pm 1.63 \mu \mathrm{g} / \mathrm{mL}, P>0.05)$ after CRF treatment, 


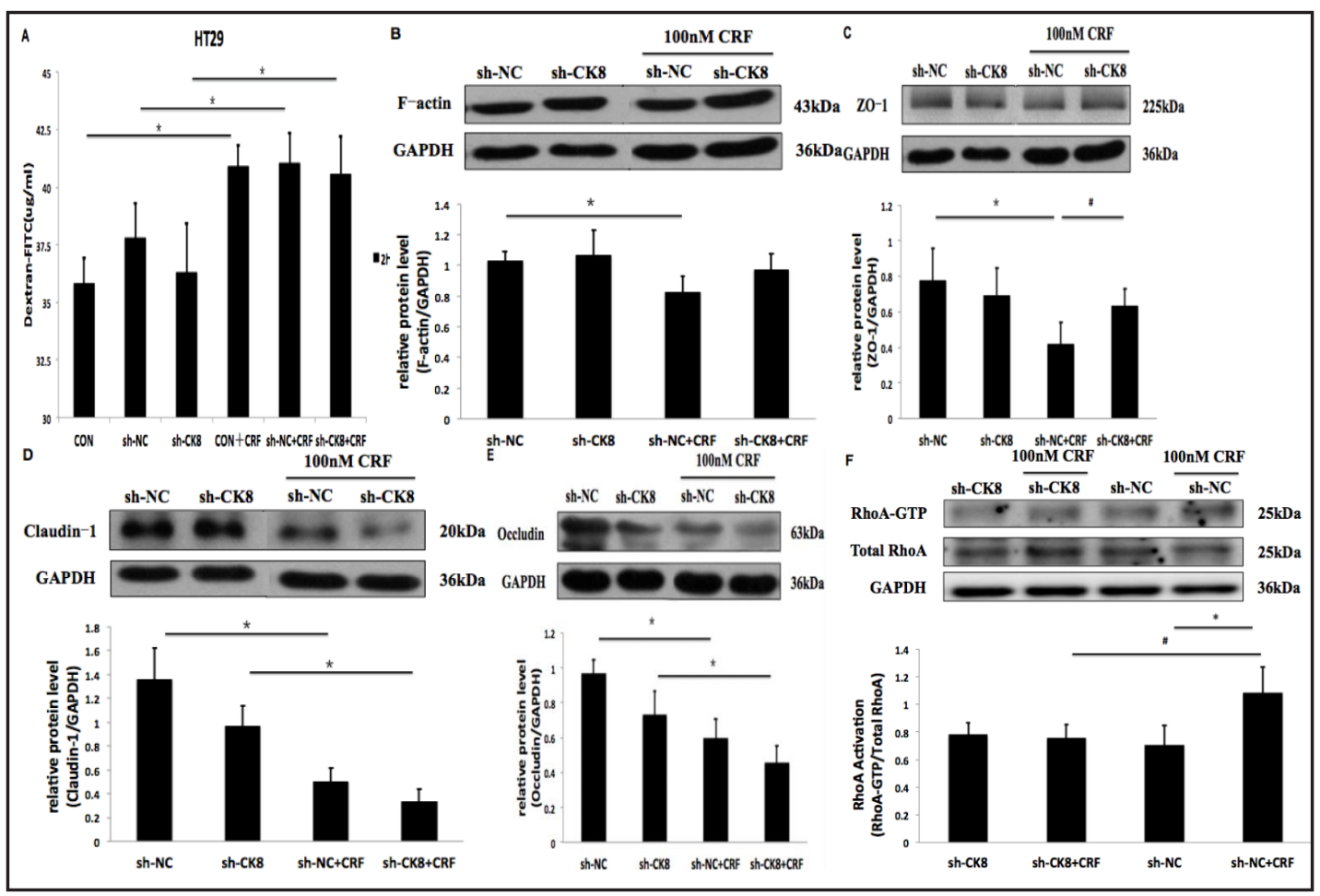

Fig. 6. Effects of CRF on the permeability and expression of TJ-related proteins in CK8-silenced HT29 cells by FITC-dextran and Western blot analysis. A) Intestinal permeability examined by FITC-labelled Dextran. Normal controls, sh-NC and sh-CK8 HT29 cells were treated with or without $100 \mathrm{nM}$ CRF for 2 h. The values are expressed as the means $\pm \mathrm{SD}(\mathrm{n}=3$ each); B-E) Western blot analysis of the expression of F-actin, ZO-1, occludin, and claudin-1 in sh-NC and sh-CK8 HT29 cells with or without CRF treatment. GAPDH was used as the loading control. The bar chart shows the relative band intensity (F-actin/GAPDH, ZO-1/ GAPDH, occludin/GAPDH, or claudin-1/GAPDH) as determined by scanning densitometry. The values are expressed as the means \pm SD ( $\mathrm{n}=3$ each); F) Activity of RhoA (RhoA-GTP), as examined by Western blotting. sh-NC and sh-CK8 cells were treated with or without $100 \mathrm{nM}$ CRF for $30 \mathrm{~min}$. RhoA-GTP expression was identified based on total RhoA. GAPDH was used as the loading control (not shown). The bar chart shows the relative band intensity (RhoA-GTP/Total RhoA), as determined by scanning densitometry. The values are expressed as the mean $\pm \mathrm{SD}\left(\mathrm{n}=3\right.$ each). ${ }^{*} \mathrm{P}<0.05 \mathrm{CRF}$ treatment groups vs. respective non-CRF treatment groups; $\# \mathrm{P}<0.05$ sh-NC+CRF group vs. sh-CK8+CRF group.FITC, fluorescein isothiocyanate; CK8, cytokeratin 8; GAPDH, glyceraldehyde-3-phosphatedehydrogenase; RhoA, Ras homologue gene family, member A; CRF, corticotropin-releasing factor; NC, negative control; GAPDH, glyceraldehyde-3-phosphate dehydrogenase.

indicating that CK8 silencing in HT29 cells could not block the increased permeability induced by CRF (Fig. 6A).

Expressions of F-actin and ZO- 1 in the sh-NC + CRF group was lower than that in the shNC group $(P<0.05)$. This decrease was blocked by CK8 silencing, as indicated by increased levels of F-actin and ZO-1 in the sh-CK8+CRF group compared with that in sh-NC + CRF cells, although the difference for F-actin was not statistically significant. No significant difference in F-actin and ZO-1 expression was observed between the sh-CK8 and sh-CK8+CRF groups, further suggesting that the CRF-induced increase in the expression of F-actin and that ZO-1 was inhibited by CK8 silencing (Fig. 6B and C). The expression of claudin-1 and occludin was decreased significantly after CRF treatment in both sh-NC and sh-CK8 cells $(P<0.05)$, indicating that CK8 silencing did not affect the CRF-induced downregulation of the expressions of claudin-1 and occludin (Fig. 6D and E). However, 30 min after CRF treatment, RhoA activity was increased significantly in the sh-NC group, whereas CK8 silencing blocked this increase in the sh-CK8+CRF group $(P<0.05$ vs. sh-NC+CRF; Fig. 6F). 


\section{Cellular Physiology Cell Physiol Biochem 2017;44:1161-1173

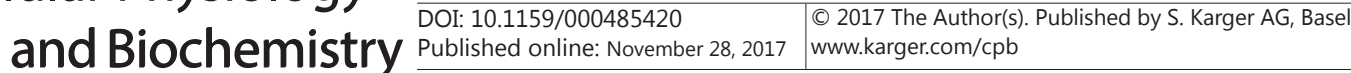 \\ Yue et al.: CRF Regulates Intestinal Epithelial Permeability by CK8 Upregulation}

\section{Discussion}

Studies have shown that CRF can directly promote the degranulation of mast cells and enhance the secretion of inflammatory mediators that increase mucosal permeability as well as intestinal adhesion and penetration of pathogens, leading to impaired functioning of the intestinal barrier $[29,30]$. Furthermore, dysfunction of the intestinal barrier causes the exudation of macromolecules from the intestinal mucosa, promoting IBS-D. Therefore, the permeability of the intestinal mucosa and function of the intestinal barrier are key factors to study the link between CRF and IBS. In this study, we explored the role of CRF in intestinal epithelial permeability in an in vitro model of the intestinal epithelial cell barrier established using the human colonic carcinoma cell line HT29, which has similar cell characteristics to normal intestinal epithelial cells. To our knowledge, this study is the first to propose the hypothesis that CRF plays an important role in mediating intestinal epithelial permeability changes through CK8.

CK8 is involved in maintaining the mechanical integrity of cells and in regulating cell adhesion and protein synthesis [31], which play an important role in maintaining the structure and function of the gastrointestinal epithelium. Moreover, CK8 can cause the re-formation of actin and affect the permeability of intestinal epithelial cells due to its close association with TJ proteins $[18,26]$. TJ proteins are divided into 2 categories according to their localization: transmembrane proteins, such as claudin, occludin, and JAM, which constitute a selective barrier; cytoplasmic proteins, which act as signalling molecules to link the membrane protein and cytoskeleton through binding to various proteins, such as $\mathrm{ZO}, \mathrm{AF} 6$, and 7H6 [5]. Various stimuli are known to induce actin remodelling and the formation of stress fibres [32]. F-actin is a major contractile protein of the cytoskeleton, and its reorganization and redistribution in epithelial cells may impair intestinal barrier function by altering the structure of intestinal TJ-associated proteins. Cytoskeletal actin links to the C-terminal region of TJ protein ZO-1 and influences its expression and structure [33]. Cytoplasmic protein ZO-1 could further bind to the $\mathrm{C}$-terminal binding sequence of the transmembrane protein claudin- 1 and participate in maintaining the stability of epithelial TJ $[6,34,35]$.

In this study, the expression of CK8 protein in HT29 cells was upregulated after CRF treatment. Furthermore, immunofluorescence images showed that cytoplasmic CK8 displayed a granular change and increased fluorescence intensity. Moreover, treatment with $100 \mathrm{nM}$ CRF could induce increased permeability in HT29 cells accompanied by opening of the TJ channel and loosening of connections in the cellular ultrastructure. The TJ proteins, claudin 1, Z0-1, and occludin manifested a decrease in expression and structural disruptions, whereas F-actin only showed decreased expression, without significant changes in protein structure and distribution. These results suggest that the stress-related factor CRF not only induces the upregulation of CK8 expression and changes in distribution but also damages the ultrastructure of TJs, as well as expression and localization of associated proteins, leading to increased permeability of the intestinal epithelial barrier.

To clarify the role of CK8 in the formation of TJs, we constructed a CK8 low-expression intestinal epithelial cell line HT29. CK8 silencing in HT29 cells could not block the increased permeability induced by CRF treatment, suggesting that other CK8-independent pathways are responsible for the effects of CRF. The expression of F-actin and ZO-1 was decreased significantly after CRF treatment in the sh-NC groups, whereas CK8 silencing reversed this decrease; these findings indicate the involvement of CK8 in mediating the effects of CRF on F-actin and ZO-1 expression. We inferred that CRF could increase intestinal epithelial permeability through intestinal epithelial actin remodelling as well as by the decreased expression and structural disruption of $\mathrm{ZO}-1$, an effect that was ostensibly mediated by the upregulation of CK8. However, the CRF-induced decrease in the expression of claudin-1 and occludin was not blocked by CK8 silencing, as indicated by downregulated levels of these proteins after the stimulation of CK8-silenced HT29 cells with CRF. Together with the lack of significant difference in the permeability of intestinal epithelial cells after CRF treatment in CK8-silenced HT29 cells compared with that in the negative control, these results suggested 


\section{Cellular Physiology Cell Physiol Biochem 2017;44:1161-1173 \begin{tabular}{ll|l} 
DOI: 10.1159/000485420 & $\begin{array}{l}\text { O 2017 The Author(s). Published by S. Karger AG, Basel } \\
\text { www.karger.com/cpb }\end{array}$ \\
\hline and Biochemistry
\end{tabular}

that CRF might affect the permeability of intestinal epithelial cells through CK8-dependent or -independent pathways.

RhoA is a small-molecule guanine nucleotide-binding protein (small G protein) belonging to the Rho (Ras homologue) family. It interacts with GTP to activate downstream effectors and participates in F-actin recombination in the cytoskeleton and influences cellular morphology, migration, adhesion, and other various biological functions [36, 37]. Various cytokines and inflammatory factors can activate the Rho/Rho kinase pathway, causing myosin light-chain phosphorylation, actin-myosin cross-linking enhancement, F-actin cytoskeleton recombination, and stress fibre formation [38]. In this study, the activity of RhoA was increased and peaked at $30 \mathrm{~min}$ after CRF administration in normal HT29 cells. A similar result was observed in sh-NC HT29 cells. CK8 may regulate actin remodelling through the Rho/Roc kinase signalling pathway [39]. Therefore, we silenced CK8 expression in HT29 cells and found that the inhibition of CK8 expression blocked the CRF-induced increase in RhoA activity. These findings suggest that CRF may be involved in the regulation of intestinal epithelial permeability through the activation of the CK8mediated RhoA pathway, regulation of actin remodelling and decrease in TJ ZO-1 expression, further inducing structural disruption.

\section{Conclusion}

We investigated the possible relationship among the stress factor CRF, stress-related protein CK8, F-actin, and intestinal mucosal TJ-related proteins and the underlying mechanisms involved in the pathogenesis of IBS. The results provide a scientific basis to explain the mechanism of stress-induced increase in the permeability of the intestinal mucosa. It is concluded that CRF may be involved in increasing intestinal epithelial permeability through CK8 upregulation-induced activation of the RhoA signalling pathway, intestinal epithelial actin remodelling, and low expression of TJ ZO-1. Other CK8-independent pathways may be involved in decreasing the expression of membrane TJ proteins, claudin-1 and occludin, which are known to contribute to the increased permeability of intestinal epithelial cells. The involvement of other factors or pathways in CRF-induced damage to the intestinal epithelial barrier needs to be further clarified in future research.

\section{Acknowledgements}

This study was supported by the Natural Science Foundation of China (No.81470814).

\section{Disclosure statement}

There are no disclosures to report.

\section{References}

1 Chang JY, Locke GR 3rd, McNally MA, Halder SL, Schleck CD, Zinsmeister AR, Talley NJ: 2010 Impact of functional gastrointestinal disorders on survival in the community. Am J Gastroenterol 2010;105:822-832.

2 Piche T, Barbara G, Aubert P, Bruley des Varannes S, Dainese R, Nano JL, Cremon C, Stanghellini V, De Giorgio R, Galmiche JP, Neunlist M: Impaired intestinal barrier integrity in the colon of patients with irritable bowel syndrome: involvement of soluble mediators. Gut 2009;58:196-201.

- Vivinus-Nebot M, Frin-Mathy G, Bzioueche H, Dainese R, Bernard G, Anty R, Filippi J, Saint-Paul MC, Tulic MK, Verhasselt V, Hebuterne X, Piche T: Functional bowel symptoms in quiescent inflammatory bowel diseases: role of epithelial barrier disruption and low-grade inflammation. Gut 2014;63:744-752. 


\section{Cellular Physiology Cell Physiol Biochem 2017;44:1161-1173 \begin{tabular}{l|l|l} 
and Biochemistry Published onlIne: November 28, 2017 & $\begin{array}{l}\text { (c) } 2017 \text { The Author(s). Published by S. Karger AG, Basel } \\
\text { www.karger.com/cpb }\end{array}$
\end{tabular}

4 Xiao L, Rao JN, Cao S, Liu L, Chung HK, Zhang Y, Zhang J, Liu Y, Gorospe M, Wang JY: Long noncoding RNA SPRY4-IT1 regulates intestinal epithelial barrier function by modulating the expression levels of tight junction proteins. Mol Biol Cell 2016;27:617-626.

5 Förster C: Tight junctions and the modulation of barrier function in disease. Histochem Cell Biol 2008;130:55-70.

6 Turner JR: Molecular basis of epithelial barrier regulation: from basic mechanisms to clinical application. Am J Pathol 2006;169:1901-1909.

7 Steed E, Balda MS, Matter K: Dynamics and functions of tight junctions. Trends Cell Biol 2010;20:142-149.

$>8$ Citi S, Denisenko N: Phosphorylation of the tight junction protein cingulin and the effects of protein kinase inhibitors and activators in MDCK epithelial cells. J Cell Sci 1995;108:2917-2926.

-9 Dai C, Guandalini S, Zhao DH, Jiang M: Antinociceptive effect of VSL\#3 on visceral hypersensitivity in a rat model of irritable bowel syndrome: a possible action through nitric oxide pathway and enhance barrier function. Mol Cell Biochem 2012;362:43-53.

10 Matsuo K, Zhang X, Ono Y, Nagatomi R: Acute stress-induced colonic tissue HSP70 expression requires commensal bacterial components and intrinsic glucocorticoid. Brain Behav Immun 2009;23:108-115.

11 Zhou Q Souba WW, Croce CM, Verne GN: MicroRNA-29a regulates intestinal membrane permeability in patients with irritable bowel syndrome. Gut 2010;59:775-784.

12 Martínez C, Rodiño-Janeiro BK, Lobo B, Stanifer ML, Klaus B, Granzow M, González-Castro AM, SalvoRomero E, Alonso-Cotoner C, Pigrau M, Roeth R., Rappold G, Huber W, González-Silos R, Lorenzo J, de Torres I, Azpiroz F, Boulant S, Vicario M, Niesler B, Santos J: miR-16 and miR-125b are involved in barrier function dysregulation through the modulation of claudin- 2 and cingulin expression in the jejunum in IBS with diarrhoea. Gut 2017;66:1537-1538.

13 Zupancic T, Stojan J, Lane EB, Komel R, Bedina-Zavec A, Liovic M: Intestinal cell barrier function in vitro is severely compromised by keratin 8 and 18 mutations identified in patients with inflammatory bowel disease. PLoS One 2014;9:e99398.

14 Alam H, Kundu ST, Dalal, SN, Vaidya MM: Loss of keratins 8 and 18 leads to alterations in alpha6beta4integrin-mediated signalling and decreased neoplastic progression in an oral-tumour-derived cell line. J Cell Sci 2011;124:2096-2106.

15 Beil M, Leser J, Lutz MP, Gukovskaya A, Seufferlein T, Lynch G, Pandol SJ, Adler G: Caspase 8-mediated cleavage of plectin precedes F-actin breakdown in acinar cells during pancreatitis. Am J Physiol Gastrointest Liver Physiol 2002;282:G450-460.

16 Bordeleau F, Myrand Lapierre ME, Sheng Y, Marceau N: Keratin 8/18 regulation of cell stiffnessextracellular matrix interplay through modulation of Rho-mediated actin cytoskeleton dynamics. PLoS One 2012;7:e38780.

17 Wald FA, Oriolo AS, Casanova ML, Salas PJ: Intermediate filaments interact with dormant ezrin in intestinal epithelial cells. Mol Biol Cell 2005;16:4096-4107.

-18 Fortier AM, Asselin E, Cadrin M: Keratin 8 and 18 loss in epithelial cancer cells increases collective cell migration and cisplatin sensitivity through claudin1 up-regulation. J Biol Chem 2013;288:11555-11571.

19 Ding Y, Lu B, Chen D, Meng L, Shen Y, Chen S: Proteomic analysis of colonic mucosa in a rat model of irritable bowel syndrome. Proteomics 2010;10:2620-2630.

20 Larauche M, Mulak A, Tache Y: Stress and visceral pain: from animal models to clinical therapies. Exp Neurol 2012;233:49-67.

-21 O'Malley D, Quigley EM, Dinan TG, Cryan JF: Do interactions between stress and immune responses lead to symptom exacerbations in irritable bowel syndrome? Brain Behav Immun 2011;25:1333-1341.

22 Zhou H, Lv B, Zhang L, Li M, Chu L, Chen MY, Chen HQ: The effect of antagonizing corticotropin releasing factor receptor 1/activating corticotropin releasing factor receptor 2 on visceral sensitivity and colonic motility of irritable bowel syndrome rats. Chin J Dig 2011; 31, 372-376.

23 Nozu T, Okumura T: Corticotropin-releasing factor receptor type 1 and type 2 interaction in irritable bowel syndrome. J Gastroenterol 2015;50:819-830.

24 Overman EL, Rivier JE, Moeser AJ: CRF induces intestinal epithelial barrier injury via the release of mast cell proteases and TNF-alpha. PLoS One 2012;7:e39935.

-25 Buckley MM, O'Halloran KD, Rae MG, Dinan TG, O'Malley D: Modulation of enteric neurons by interleukin-6 and corticotropin-releasing factor contributes to visceral hypersensitivity and altered colonic motility in a rat model of irritable bowel syndrome. J Physiol 2014;592:5235-5250. 


\section{Cellular Physiology Cell Physiol Biochem 2017;44:1161-1173 \begin{tabular}{ll|l} 
and Biochemistry & DOI: 10.1159/000485420 & $\begin{array}{l}\text { (c) } 2017 \text { The Author(s). Published by S. Karger AG, Basel } \\
\text { www.karger.com/cpb }\end{array}$
\end{tabular}

26 Wallon C, Persborn M, Jonsson M, Wang A, Phan V, Lampinen M, Vicario M, Santos J, Sherman PM, Carlson M, Ericson AC, McKay DM, Soderholm JD: Eosinophils express muscarinic receptors and corticotropinreleasing factor to disrupt the mucosal barrier in ulcerative colitis. Gastroenterology 2011;140:1597-1607.

-27 Zbytek B, Pikula M, Slominski RM, Mysliwski A, Wei E, Wortsman J, Slominski AT: Corticotropin-releasing hormone triggers differentiation in HaCaT keratinocytes. Br J Dermatol 2005;152:474-480.

-28 Zoumakis E, Margioris AN, Stournaras C, Dermitzaki E, Angelakis E, Makrigiannakis A, Koumantakis E, Gravanis A: Corticotrophin-releasing hormone (CRH) interacts with inflammatory prostaglandins and interleukins and affects the decidualization of human endometrial stroma. Mol Hum Reprod 2000;6:344351.

29 Keita AV, Soderholm JD, Ericson AC: Stress-induced barrier disruption of rat follicle-associated epithelium involves corticotropin-releasing hormone, acetylcholine, substance P, and mast cells. Neurogastroenterol Motil 2010;22:770-778, e221-222.

30 Teitelbaum AA, Gareau MG, Jury J, Yang PC, Perdue MH: Chronic peripheral administration of corticotropinreleasing factor causes colonic barrier dysfunction similar to psychological stress. Am J Physiol Gastrointest Liver Physiol 2008;295:G452-459.

-31 Hesse M, Magin TM, Weber K: Genes for intermediate filament proteins and the draft sequence of the human genome: novel keratin genes and a surprisingly high number of pseudogenes related to keratin genes 8 and 18. J Cell Sci 2001;114:2569-2575.

-32 Kimura K, Ito M, Amano M, Chihara K, Fukata Y, Nakafuku M, Yamamori B, Feng J, Nakano T, Okawa K, Iwamatsu A, Kaibuchi K: Regulation of myosin phosphatase by Rho and Rho-associated kinase (Rhokinase). Science 1996;273:245-248.

-33 Ma T, Liu L, Wang P, Xue Y: Evidence for involvement of ROCK signaling in bradykinin-induced increase in murine blood-tumor barrier permeability. J Neurooncol 2012;106:291-301.

-34 Gonzalez-Mariscal L, Quiros M, Diaz-Coranguez M: ZO proteins and redox-dependent processes. Antioxid Redox Signal 2011;15:1235-1253.

-35 van Hinsbergh VW, van Nieuw Amerongen GP: Intracellular signalling involved in modulating human endothelial barrier function. J Anat 2002;200:549-560.

-36 Arnold TR, Stephenson RE, Miller AL: Rho GTPases and actomyosin: Partners in regulating epithelial cellcell junction structure and function. Exp Cell Res 2017;358:20-30.

-37 Torres-Cruz FM, Rodríguez-Cruz F, Escobar-Herrera J, Barragán-Andrade N, Basurto-Islas G, Ripova D, Ávila J, Garcia-Sierra F: Expression of Tau Produces Aberrant Plasma Membrane Blebbing in Glial Cells Through RhoA-ROCK-Dependent F-Actin Remodeling. J Alzheimers Dis 2016;52:463-482.

-38 Wettschureck N, Offermanns S: Rho/Rho-kinase mediated signaling in physiology and pathophysiology. J Mol Med (Berl) 2002;80:629-638.

39 Wallon C, Persborn M, Jonsson M, Wang A, Phan V, Lampinen M, Vicario M, Santos J, Sherman PM, Carlson M, Ericson AC, McKay DM, Soderholm JD: Eosinophils express muscarinic receptors and corticotropinreleasing factor to disrupt the mucosal barrier in ulcerative colitis. Gastroenterology 2011;140:1597-1607. 